\title{
メッセージ交換を用いた分散型スケジューリング システムの並行実行性能評価
}

\author{
北 島 禎 二**西 谷 紘一** \\ 長谷部 伸 治*** ·橋 本 伊 織***
}

Performance Evaluation of the Distributed

Scheduling System Using Message Passing ${ }^{\dagger}$

Teiji Kitajima*, Hirokazu Nishitani**,

Shinji HASEBE ${ }^{* * *}$ and Iori HASHIMOTO ${ }^{* * *}$

\begin{abstract}
A distributed scheduling system is proposed for processes consisting of a sequence of production stages. In the proposed system, an individual sub-scheduling system is installed for each stage. A whole schedule is generated by repeating the schedule generation at each sub-system and by exchanging data among sub-systems using message passing. The simulation results show that the schedule generated by the proposed system is as good as the one obtained by the centralized scheduling method. Furthermore, by using multiple PCs concurrently, the scheduling time can be reduced drastically compared with the case where a single PC is used.
\end{abstract}

Key Words: scheduling, distributed system, concurrent processing, inter-process communication

\section{1.はじめに}

多品種の製品を生産している生産設備では, 装置の故障 や増設, 生産スケジュールの評価指標の変更, 特急品への対 応など, 設備を取り巻く環境が絶えず変化している。スケ ジューリングシステムは，これらの変化に的確に対処できな ければならない。しかしこれらの様々な変化に対処できるよ うにしょうとすると, システムは非常に大規模, 複雑なもの となってしまう。これは従来の管理システムが，スケジュー リングの対象となる生産設備全体を一括管理し, 設備全体の スケジュールを作成することを前提にシステムが構成されて いるためである．生産スケジューリング問題を複数の部分問 題に分割し，部分問題ごとに独立したエージェントが解の最

†第 10 回自律分散システム・シンポジウムで発表 (1998.1)

* 豊橋技術科学大学 工学部 豊橋市天伯町雲雀ヶ 丘 1-1

** 奈良先端科学技術大学院大学 情報科学研究科 生駒市高山町 8916-5

*** 京都大学 工学研究科 京都市左京区吉田本町

* Department of Production Systems Engineering, Toyohashi University of Technology, Toyohashi

** Graduate School of Information Science, Nara Institute of Science and Technology, Ikoma

*** Department of Chemical Engineering, Kyoto University, Sakyo-ku, Kyoto

(Received January 19, 1998)

(Revised February 8, 1999)
適性を代償としながらも相互干渉を抑えて，できるだけ並列 に，しかも矛盾のないように各部分問題を制御できれば，全 体としての問題解決効率を改善することができる，そのため 現在，分散協調スケジューリング手法に関する研究が活発に 進められるようになってきた1).

現実の生産設備では一般に, 一つ以上の装置からなる“工 程”を単位として生産管理が行われている場合が多く，これ らの構成単位ごとに生産順序や時間の割り振りに関して多く のノウハウを有している。したがって工程単位でスケジュー リングを行うことができれば, 工程単位ごとにシステムの保 守や修正が可能となり, 従来の集中管理型の生産管理システ ムが潜在的に抱える問題を解決できる可能性がある。また一 方で, 実際の生産現場においても各現場単位でパーソナル． コンピュータ（PC）の導入が積極的に行われており，これら の計算機間をつなぐための計算機ネットワーク環境の整備が 進められている.

これらの背景を踏まえ, 本研究では, ネットワークでつな がった計算機資源が工程単位ごとに分散して存在するような 環境を想定し，ネットワーク環境下で稼働する分散型のスケ ジューリングシステムを提案する. 提案するシステムは, 各 工程ごとにそれぞれ一台の計算機上に実装したサブシステ ムが互いに情報を交換しながら独自にスケジューリングを繰 り返すことによって, 設備全体として実行可能でかつ準最適 なスケジュールを導出する．提案するシステムの実用可能性 


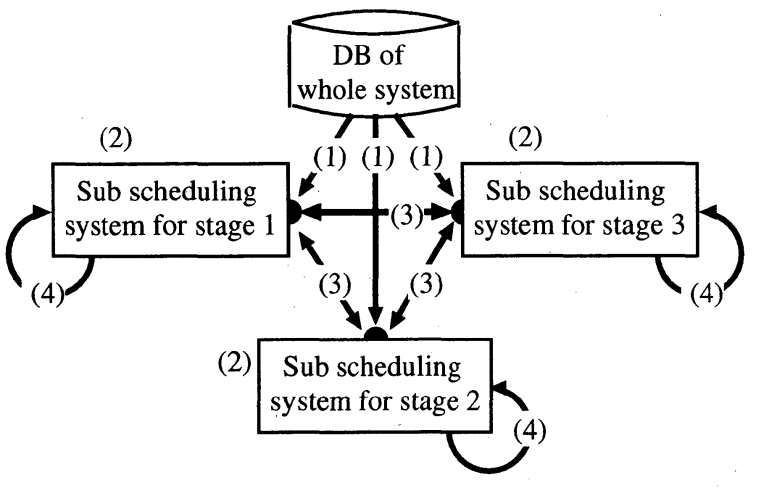

(1) Obtain the demand data

(2) Generate an initial schedule

(3) Exchange the schedule data

(4) Reschedule \} Step

Fig. 1 Distributed scheduling system

を検討するため，実際に複数の計算機を用いて並列にスケ ジューリングを行うことによって, 開発したシステムの分散 環境下での性能を従来のシステムと比較した.

\section{2. 分散型スケジューリングシステム}

本研究では, 複数の異なった工程からなる多工程の生産設 備でのスケジューリング問題を対象とした. 説明を簡単にす るため, 以下, 各工程は単一の装置からなると仮定するが, 各工程が複数の装置からなる場合も同様に扱うことができる. また各ジョブの納期および各装置上での処理時間, 異なる製 品品種間の切換えに要するコストなどは与えられるものとし, 工程間では中間製品を自由に保持できるものとする。このよ うな対象に対して, 各ジョブの納期遅れペナルティおよび各 工程の切換えコストと最後に処理する作業の終了時刻の重み 付き和を評価とするスケジューリング問題について検討した。

筆者らがこれまで提案してきた分散型スケジューリングシ ステムを Fig. 1 に示す ${ }^{2) ~ 5)}$. 全体のシステムは, 受注情報 を扱うデータベースと, 各工程ごとに実装されたサブスケ ジューリングシステム (以後, Sub-Scheduling System, 略 して“Sub-SS”と呼ぶ）によって構成される.

Sub-SS はデータベースから受注情報を受け取り（1）, 独 自に探索的手法によってスケジュールを作成する（2）。し かしながら各 Sub-SS が独自にスケジューリングを行うと， 一般的には設備全体として実行可能なスケジュールになら ない。そこで Sub-SS は他工程の Sub-SS から作成したスケ ジュールに関する情報を受け取り（3），その情報を基に再 スケジューリングを行う（4）．以後, 各 Sub-SS は情報交換 と再スケジューリング（これら一連の操作を合わせて 1 ス テップと呼ぶ）を繰り返し，設備全体として実行可能なスケ ジュールを作成していく.

本手法は以下の二つの特徴を有している。

・各Sub-SS は, 自身に必要な機能や情報を独自に保有し

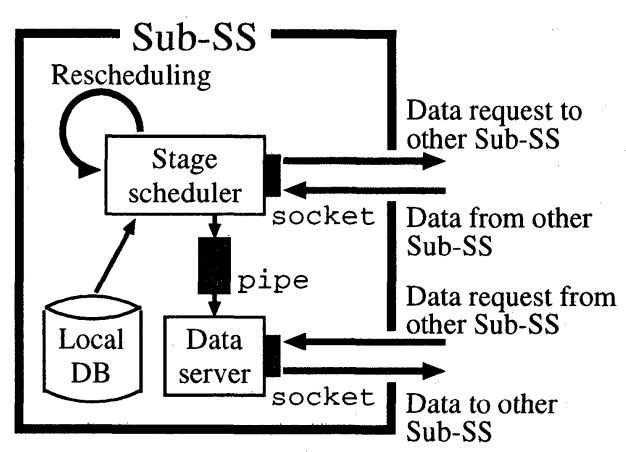

Fig. 2 Sub scheduling system (Sub-SS)

ており，他の Sub-SS および設備全体を管理するシステム からスケジュール作成に関する直接の命令は受けない.

・各Sub-SS は, 予め与えられた独自の評価基準にしたがっ てスケジュールを作成する機能を有している.

これまでの筆者らの研究では，このようなシステムに適し た分散型のスケジューリング手法について検討してきたが, 実際にはすべての Sub-SS を1台の計算機上に実装しており, 複数の計算機による並行処理を行っていなかった. 本論文で は，実際に複数の計算機を用いて並列にスケジューリングを 行うことによって, 提案するシステムの分散環境下での性能 について検討する。

\section{3. サブスケジューリングシステム}

\section{1 システム構成}

それぞれの Sub-SS は Fig. 2 に示すように，自工程のス ケジューリングと他工程から情報を取得する機能を持ったス ケジューラ (以後, Stage Scheduler, 略して“SS”と呼ぶ)， 他工程に自工程のデータを渡すデータサーバ（以後, Data Server，略して“DS”と呼ぶ），および自工程固有の情報を 保持するデータベースから構成される.

SS は自 Sub-SS 内の DS, 他工程の DS および受注情報を 扱うデータベースとプロセス間通信によって情報の授受を 行う。 今回, 各 Sub-SS はそれぞれ 1 台の UNIX (BSD/OS 2.0.1) マシン上に実装し，それぞれの通信にはUNIX に用 意されている pipe システムコールと socket システムコー ルを利用した。

3.2 スケジューリングァルゴリズム

各工程のスケジューリングを担当する SS は, 以下の手順 でスケジューリングを行う.

(1) スケジューリングデータの作成

（2）到着時刻基準最早開始時刻，納期基準最遅開始時刻 の計算

（3）初期スケジュールの作成

(4) スキップ判定

（5），他工程との情報交換と必要デー夕の計算

(6) スケジュール改良

（7）収束判定 
（8）スケジュールデータの pipeへの書き出し

(9) 終了判定

3.2 .1 スケジューリングデータの作成

受注情報を扱うデータベースに問い合わせて生産要求に関 するデータを受け取った後, 各工程固有の情報を自 Sub-SS のデータベースから読み込み，スケジューリング用のパラ メータ（切換えコストなど）および作業デー夕を作成する.

3.2 .2 到着時刻基準最早開始時刻，納期基準最遅開始時 刻の計算

各 SS は作成した作業デー夕を基に，各作業に対してスケ ジュールに依存しないつぎの時刻を計算する。

- 到着時刻基準最早開始時刻（ $E_{o} ）$ : 作業 0 の属するジョ ブを生産設備に到着後ただちに待ちなしで行った際の各工 程での作業 $o$ の開始時刻.

- 納期基準最遅開始時刻 $\left(F_{o}\right)$ : 作業 $O$ の属するジョブを 待ちなしで行った際に納期を満たすことのできる各工程で の作業 $o$ の最遅開始時刻.

3.2 .3 初期スケジュールの作成

他工程のスケジュールを考慮しないで，初期処理順（読み 込んだジョブデータの並び順）での開始時刻と終了時刻を前 詰めで計算し, 現在のステップ数, 開始/終了時刻, 収束》 ラグを pipeに書き出す、

3.2.4 スキップ判定

SS は他の Sub-SS の 1 ステップ前のデータを基にスケ ジューリングを行う。このような手法では全体として実行 不可能なスケジュールが周期的に発生し, 実行可能なスケ ジュールが得られない場合がある. Fig. 3 はそのような一例 である，あるステップで Fig. 3 (a) のような（実行不可能な） スケジュールが得られたとする。このスケジュールを基に各 SS が独立して再スケジューリングを行うと，Fig. 3 (b) のよ うなスケジュールが得られる場合がある。ささらに Fig. 3 (b) のスケジュールに基づいて, 各 SS ごとに再スケジューリン グを行うと. 再び Fig. 3 (a) のようなスケジュールに戻って しまい, 以後, この二つのスケジュールが繰り返し得られる, という現象が起こりうる.

このような事態を避けるため本システムでは，他工程と の情報伝達の後, 各 Sub-SS が予め与えられた確率で再スク ジューリングを行わないという操作（スキップと呼ぶ）をと り入れた。この操作によって，スキップした工程は同一のス ケジュールのデー夕を 2 回続けて他工程に渡すことになり， 上記のような現象は起こりにくくなる．たとえば Fig. $3(\mathrm{~b})$ のスケジュールにおいて，工程 2 の Sub-SS が再スケジュー リングをスキップすることによって, Fig. 3 (c) のような実 行可能なスケジュールが得られることになる．

そこで予め与えられたスキップ確率にしたがって，そのス テップでのスケジューリングをスキップするかしないかのフ ラグを立て，スキップする場合は「3.2.7 収束判定」へ飛び (ただし第 1 ステップではスキップしない)，再スケジューリ ングは行わないようにした。
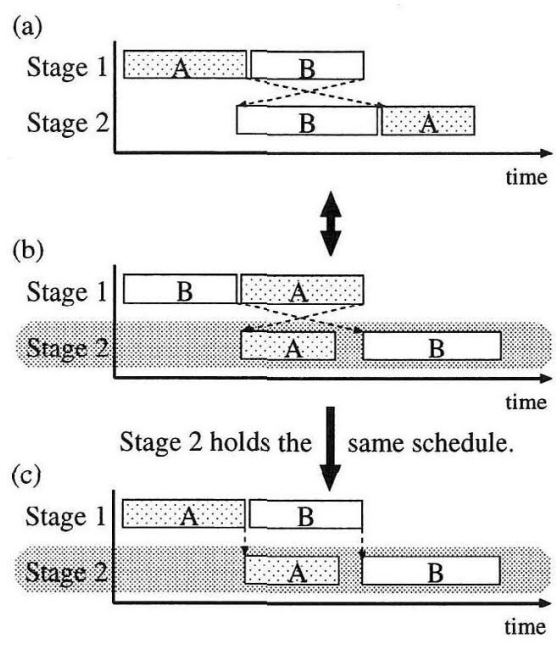

Fig. 3 Cyclic generation of the same schedule

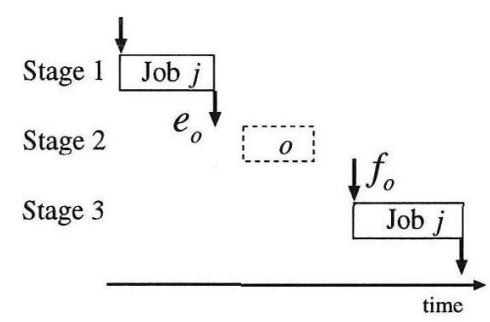

Fig. 4 Schedule data transferd from other stages

\section{2 .5 他工程との情報交換と必要データの計算}

各 SS は他工程の DS にスケジュールに関する情報を要求 し，受け取った情報を基に各作業に対して以下の二つの值を 計算する。

- 暫定最早開始時刻 $\left(e_{o}\right)$ : 直前の工程での作業。の属す るジョブ（ジョブ $j$ とする）の終了時刻.

- 暫定最遅終了時刻 $\left(f_{o}\right)$ : 直後の工程での作業 $o$ の属す るジョブの開始時刻.

たとえばスケジュール改良途中のあるステップで Fig. 4 の ようなスケジュールが得られたとすると，工程 2 の SS は次 回のスケジュール改良時に，作業 $o$ の暫定最早開始時刻，暫 定最遅終了時刻としてそれぞれ図中に示した $e_{o}, f_{o}$ を参照 する。

3.2.6 スケジュール改良

各作業の暫定最早開始時刻，暫定最遅終了時刻を考慮して スケジュールを改良する。

本報では，

- 近傍処理順の発生

- 作業開始時刻の計算

・スケジュールの評価計算

- 解の更新判定

という手順を繰り返し行うことにより，スケジュールを探 索的に改良するアルゴリズムを採用した，解の更新には SA （Simulated Annealing）法を用い，局所解に陥るのを防い 
だ. 近傍処理順は，一つの作業をランダムに選び，その作業 の処理順をランダムに変更することによって発生させた．

ある工程で $i$ 番目に処理される作業 $o_{i}$ の操作開始時刻 $t_{o_{i}}$ は, 次式のように, 同装置内で先行する作業の終了時刻, 到 着時刻基準最早開始時刻 $E_{o_{i}}$, 暫定最早開始時刻 $e_{o_{i}}$ のうち 最も遅い時刻とした.

$$
t_{o_{i}}=\max \left\{t_{o_{i-1}}+P_{o_{i-1}}, E_{o_{i}}, e_{o_{i}}\right\}
$$

ここで

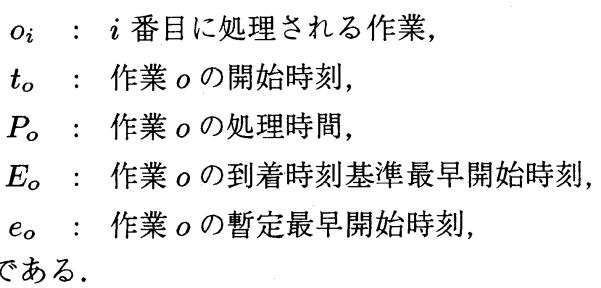

各 SS が自工程のみならず，設備全体の状況を判断してス ケジュールを作成するためには，設備全体の評価に関する情 報を各工程の評価指標に組み込む必要がある，本研究では納 期遅れペナルティの和を設備全体の評価指標の一部としてい る. 各工程での作業終了時刻が納期基準最遅開始時刻より遅 ければ，最終工程においても納期を満たすことはできない， よって納期基準最遅開始時刻からの遅れの和を最終工程以外 の工程においても評価に組み込むことにした．また作業終了 時刻がその作業の暫定最遅終了時刻より遅ければ，得られた 解は実行不可能である。よって暫定最遅終了時刻からの遅れ も評価に加え，以下に示す評価指標を用いた。

$$
\begin{aligned}
&(\text { 評価 })=(\text { 切換えコストの和 }) \\
&+\quad(\text { 工程で最後に処理する作業の終了時刻 }) \\
&+\quad(\text { 納期基準最遅開始時刻からの遅れに } \\
&\quad \text { 対するペナルティの和 }) \\
&+\beta \quad(\text { 暫定最遅終了時刻からの遅れの和 })
\end{aligned}
$$

ここで $\beta$ は上下流の工程との情報交換が繰り返されるごとに 増加させるパラメータである。この重み係数を徐々に増加さ せることによって，各 SS は $\beta$ が小さいときは各工程の評価 のみを考え， $\beta$ が大きくなるにしたがって他工程と協調し， 次第に実行可能なスケジュールを導出していく.

\section{2.7 収束判定}

直前のステップとスケジュールの変更がなく, 実行可能（暫 定最遅終了時刻からの遅れがない) で，かつスキップしてい ないかあるいは収束フラグがすでに立っていれば，収束フラ グを立てる．

3.2 .8 スケジュールデータの pipe への書き出し

現在のステップ数, 各作業の開始/終了時刻, 収束フラグ を pipeに書き出す.

\section{2 .9 終了判定}

収束フラグが立っていれば他工程の収束フラグを取得し， 全工程が収束していれば終了する。
終了していなければ，ステップ数を増やし,「3.2.4 スキッ プ判定」に戻る.

3.3 メッセージ交換による情報伝達アルゴリズム

SS は他工程のスケジュールデータおよび終了判定情報を 以下の手順にしたがって取得する。

\subsubsection{SS のデー夕要求手順}

各 SS は以下の手順にしたがって他工程の DS に要求を出 し，自身に必要なデー夕を更新する。

（1）要求を出す DS（自工程以外，工程順）を決定する。

（2）上で決めた DS に要求メッセージ（暫定最早開始時 刻，暫定最遅終了時刻，収束フラグのいずれか）を出す.

(3) DS から工程 ID，ステップ数および要求メッセージ に応じたデータを受け取る。

（4）受け取ったデータのステップ数が，自工程のステッ プ数より 2 以上小さければ（終了判定時は自工程のステッ プ数未満であれば)，適当な時間 sleep した後，(2）に戻る。 （5）要求が暫定最早開始時刻あるいは暫定最遅終了時刻 であれば，各作業のデー夕（ジョブ ID，暫定最早開始時 刻，暫定最遅終了時刻を計算するためのデー夕）を切り出 し，暫定最早開始時刻，暫定最遅終了時刻を計算して，(1) に戻る。

要求が収束フラグであれば, 各 SS で保持している他工 程の収束フラグを更新して,(1) に戻る。

3.3.2 DS のデータ送信手順

各 DS は要求受け付けの無限ループ状態で，以下の手順に したがって SS からの要求メッセージに対して返答する.

（1） SS からの要求受け付け状態で待機する.

（2）SSからの要求メッセージを受け取ったら, pipe上 にデータがあれば，そのデー夕を読み出す（読み出しに よって, pipe 上のデータはなくなる）。

（3）デー夕を送信するための子プロセスを起ち上げ, (1) に戻る。

（4）子プロセスは, 要求メッセージに応じたデー夕を送 信し, 終了する.

\subsection{3 情報伝達の例}

以上をまとめると, Sub-SS 間の情報伝達は Fig. 5 のよう になる。縦の線がそれぞれ各工程の SS と DS のプロセスの進 行状況を，その間を結ぶ矢印がプロセス間の通信を表してい る. 工程 2 の SS（以下，工程 $k$ の SS と DSをそれぞれ “SS $k "$, “DS $k$ ”と略す）を例に図の説明をする.

SS 2 は第 $i$ ステップのスケジューリング後, 第 $(i+1)$ ス テップに移る。まずpipeにデータを書き出し，DS 3 に暫定 最遅終了時刻のデー夕を要求する. DS 3 はSS 2 の要求を受 けて, pipeからデー夕を読み出そうとするが，この時点で は pipeにデータが存在しないため, DS 3 のデー夕は更新さ れないまま，SS 2 にデー夕を送る.SS 2 では，DS 3 から受 け取ったデータが第 $(i-1)$ ステップのもので, 必要な第 $i$ ス テップのものではなかったので, 適当な時間 sleep した後, 再びDS 3 にデー夕を要求する。このとき工程 3 では，ちょ 


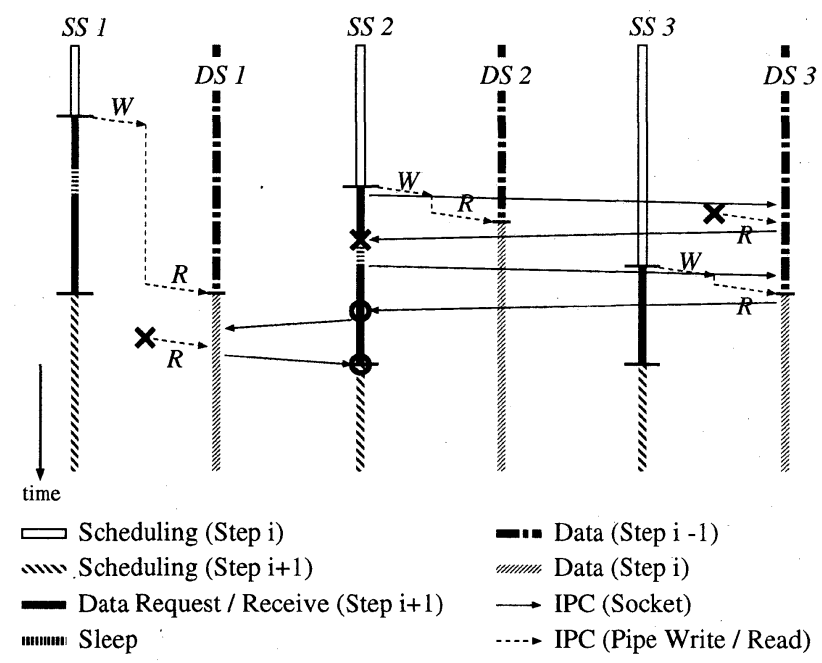

Fig. 5 Inter-process communication among Sub-SS's

うど第 $i$ ステップのスケジューリングが終了したので，今度 は第 $i$ ステップのデータを pipe から読み出して, DS 3 上の データを更新し，そのデータをSS 2 に返す. SS 2 では, DS 3 からデー夕を受け取り，続いて DS 1 に暫定最早開始時刻 のデー夕を要求し, 必要なデー夕を受け取る. 必要な他工程 のデータが全てそろったので, SS 2 は第 $(i+1)$ ステップの スケジューリングを開始する. 工程 1,3 も同様の処理により 他工程からデー夕を取得する（図が繁雑になるため, Fig. 5 では省略した）。

このように一つの工程の処理を，他工程に情報を要求する 部分 $(\mathrm{SS})$ と要求に答える部分 (DS) に分けることによっ て，工程間の情報交換の際にデッドロックが生じないように した.

\section{4. 数 值実験}

\section{1 例題}

数值実験の例題として, 3 工程のフローショップとジョブ ショップ型の問題を採用した. 対象設備では 4 種類の製品を 生産し, フローショップ型では全てのジョブを工程 $1 \rightarrow 2 \rightarrow$ 3 の順に, ジョブショップ型では品種によって, 工程 $1 \rightarrow 2$ $\rightarrow 3,3 \rightarrow 2 \rightarrow 1,2 \rightarrow 3 \rightarrow 1,1 \rightarrow 3 \rightarrow 2$ の順に処理される. 各工程でのジョブの切換えコストは続けて生産する製品の品 種によって異なる，スケジューリングの対象となるジョブの 数は 40 で, ジョブごとに異なる納期を持つ.

各工程での処理時間と切換えコストを変えた問題を，フ ローショップ, ジョブショップ型それぞれについて 21 個作成 し, 切換えコスト, 各工程で最後に処理する作業の終了時刻, 納期遅れペナルティの重み付き和を最小とするスケジュール を求める問題を本システムで解いた。

\section{2 比較手法}

得られるスケジュールの良否は, 提案した手法が現実問題 に適用可能か否かを判断する際の重要な指標となる。そこで
Table 1 Parameters for the numerical experiments

\begin{tabular}{l}
\hline Distributed system \\
Initial temperature: (P.I. of initial schedule) $\times 0.05$ \\
Number of new schedules generated \\
at each temperature: 250 \\
Number of times of temperature reduction: 100 \\
Temperature reduction factor: 0.95 \\
Probability of skipping the schedule generation: 0.2 \\
Centralized system \\
Initial temperature: (P.I. of initial schedule) $\times 0.05$ \\
Number of new schedules generated \\
at each temperature: 250 \\
Number of times of temperature reduction: 100 \\
Temperature reduction factor: 0.95 \\
\hline \hline
\end{tabular}

設備全体を同時に考慮してスケジュールを作成する従来の集 中的な手法によって得られた解と, 提案したシステムによっ て得られた解とを比較することとした．比較の対象としたス ケジューリング手法は, 発生させた初期スケジュールを逐次 改良していくことによって解を求める手法である。解が局所 的な最適解にトラップされる可能性を減らすため, 変更した スケジュールの受け入れの判断には SA 法を用いた。この際 のスケジュールの評価としては, 分散型の場合のように実行 可能性を考慮するための人為的な項を含まない本来の評価指 標である，全工程の切換えコストと最後に処理する作業の終 了時刻, および各ジョブの最終工程での納期遅れぺナルティ の重み付き和を採用した。 以後，この手法を集中型と呼ぶ (アルゴリズムは付録 $\mathrm{A}$ 参照)。この集中型では前節で提案し た分散型手法と異なり，解の探索は常に実行可能解の範囲の 中で設備全体の評価を最適化するように遷移を行う.

また実際に複数の計算機を用いてスケジューリングを行う ことによって，計算時間がどの程度短縮されるかをみるため， 手法自体は分散型ではあるが，1 台の計算機上で全工程のス ケジュールを作成するプログラム ${ }^{2), 3)}$ とも比較した．以後， この手法を分散型 1 と呼び, Sub-SS を各 1 台の計算機に実 装したシステムを分散型 2 と呼ぶ（両者を特に区別しない場 合は, 単に分散型と呼ぶ).

分散型の手法では, 実行可能解が得られるまでに要する時 間は問題によって異なる。さらに分散型 2 では, Sub-SS 間 の通信のタイミングによっては, 同一の問題に対しても実行 ごとにスケジューリングに要する計算時間は異なってしまう. 今回は集中型での CPU 時間と分散型 1 の CPU 時間をほほ 等しくなるように，集中型における同一温度でのスケジュー ル生成数を決定した。なお分散型 2 での 1 ステップ内のスケ ジュール生成回数は分散型 1 と同じとした. 全ての試行で共 通に用いたパラメータの值を Table 1 に示す.

\section{3 実行結果}

3 工程ジョブショップ問題のスケジュール改良過程におけ る各工程の評価の推移の例を Fig. 6 に示す. 図では各工程と も, 本来の評価指標である各工程の切換えコストと最後に処 理する作業の終了時刻および納期遅れペナルティの和, 暫定 

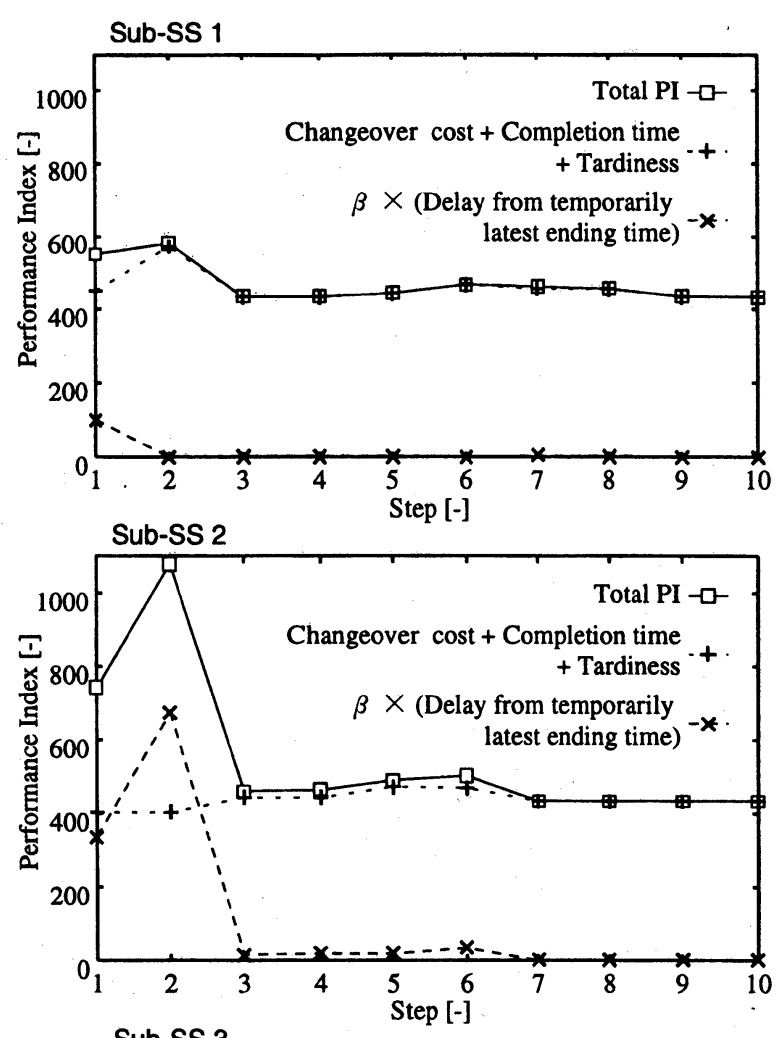

Sub-SS 3

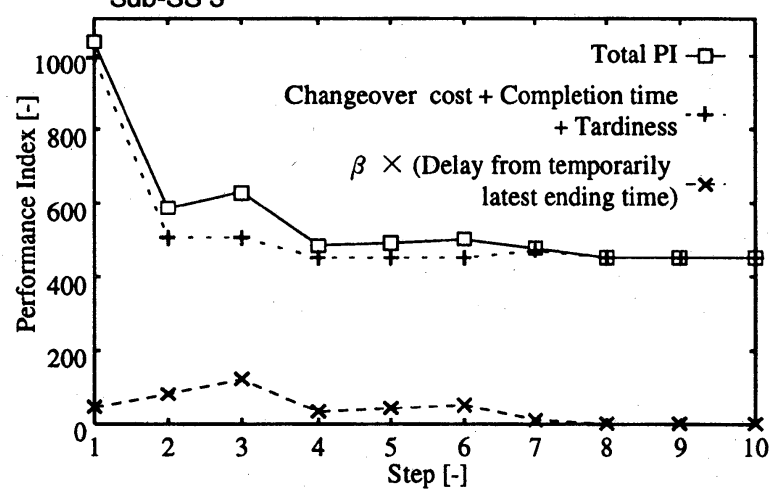

Fig. 6 Improvements of the schedule at each production stage

最遅終了時刻からの遅れに対する重み付きペナルティ, それ らの重み付き和を示した．各工程は独自にそれぞれ特有の重 み付き和を徐々に改良しながら, 暫定最遅終了時刻からの遅 れを最終的に 0 とし, 全体として実行可能な解を得ている.

フローショップ, ジョブショップ問題のそれぞれについて, 21 回の試行で得られたスケジュールの評価と CPU 時間およ び実行時間（DECpc XL590, Pentium $90 \mathrm{MHz}$ 使用）とそ れらの平均値を Table 2 および Table 3 に示す. 評価は集 中型で得られたスケジュールの評価值を 100 とした場合の, それぞれの分散型で得られた評価值の比である．よってこの 值が小さいほど集中型に比べて良いスケジュールが得られた ことを示している.また分散型では, 実行可能解を得るの に要したステップ数をあわせて載せた：なお分散型 2 では, CPU 時間は全 Sub-SS のCPU 時間の合計を, 実行時間は全
Sub-SS の中で最長のものを採用した.

表から, 分散型でも集中型と比べて遜色のない久ケジュー ルが得られていることがわかる。 また分散型 2 では試行ごと にバラッキはあるものの, 分散型 1 と比べて CPU 時間, スケ ジュール生成回数（ステップ数）はほほ同程度ながら実行時 間は約半分となっている。なおスケジューリングによる CPU の占有率は, 集中型, 分散型 1 では共に平均 $99.2 \%$ (フロー ショップ問題)， $99.5 \%$ (ジョブショップ問題）とほほ CPU を使い切っていた。

一方, 分散型 2 の場合は他工程からのデータ待ちで sleep しており，全体の実行時間は各ステップで最も計算時間の長 い工程に支配される．今回の例題では各工程がスケジューリ ングしなければならない作業数は等しいが, スキップした工 程は他工程がそのステップの計算を終えるまで待たなけれ ばならないため, 理想的な場合でも各工程ともスキップ確率 分の時間は待ちが発生してしまう。今回は各工程のスキップ 確率は 0.2 としたので, CPU 占有率は最高でも $80 \%$ とい うことになる。実際の值は, 各 Sub-SS の平均は $67.8 \%$ ( ローショップ問題)， $57.2 \%$ (ジョブショップ問題）という結 果であった．占有率が低い原因としては，通信の処理にかか るオーバーヘッドのほか, 今回とった情報交換の方法では, 最初に選んだ相手先から応答があるまで待ち, その間に他工 程にアクセスしないといった，相手先の選び方の巧拙が影響 している.

本手法では各工程が解を収束させやすくするためにスキッ プ操作をとり入れた. 今回行った数值実験では全てのケース において実行可能な解が得られたが，このスキップ操作に よって必ずしも解の収束性が保証されるわけではない，有限 時間内に必ず収束するアルゴリズムとするためには，スケ ジュール改良のステップ数がある上限值を越えた後には，第 1 工程から順番にスキップを発生させるなどの方法により解 を強制的に収束させるための仕組みを考える必要がある。

\section{5. 結論}

各工程のスケジューリングを担当するサブシステムが互 いに情報交換を行いながら工程独自の評価に基づいてスケ ジュールを改良していく, 分散型スケジューリングシステム を開発した。

全体のスケジューリングシステムを構成するサブ・スケ ジューリングシステムは, 自工程のスケジューリングと他工 程から情報を取得する機能を持ったスケジューラ, 他工程に 自工程のデー夕を渡すデータサーバ, および自工程にローカ ルな情報を保持するデータベースから構成される．提案した システムでは, 各工程独自の、スケジュール改良と上下流の工 程との情報交換を繰り返すことにより，設備全体として実行 可能で準最適なスケジュールを導出する。この手法の特徽は, スケジュール作成に関して設備全体を管理するシステムを持 たないこと，および各工程のスケジューリングシステムが解 を探索的に改良する機能を有していることである。 
T.SICE Vol.35 No.4 April 1999

Table 2 P.I., CPU time and execution time (Flowshop)

\begin{tabular}{|c|c|c|c|c|c|c|c|c|c|c|}
\hline \multirow{2}{*}{ Run No. } & \multicolumn{2}{|c|}{ P.I. } & \multicolumn{5}{|c|}{ CPU Time [s] (No. of Steps) } & \multicolumn{3}{|c|}{ Execution Time $[\mathrm{s}]$} \\
\hline & Dist. 1 & Dist. 2 & Cent. & Dis & 1 & Dist. & 2 & Cent. & Dist. 1 & Dist. 2 \\
\hline 0 & 91.3 & 87.9 & 128.1 & 97.2 & (7) & 103.0 & (7) & 128.7 & 97.9 & 50.8 \\
\hline 1 & 86.0 & 85.1 & 124.5 & 149.5 & (10) & 97.9 & (7) & 25.6 & 150.3 & 50.8 \\
\hline 2 & 83.3 & 80.6 & 124.4 & 123.7 & (8) & 142.6 & (11) & 125.4 & 124.5 & 75.1 \\
\hline 3 & 87.7 & 85.2 & 124.5 & 123.5 & (9) & 98.0 & (7) & 125.3 & 124.8 & 52.7 \\
\hline 4 & 90.3 & 87.9 & 126.0 & 170.5 & (10) & 120.1 & (9) & 127.0 & 171.8 & 62.8 \\
\hline 5 & 91.3 & 88.1 & 127.0 & 90.6 & (5) & 138.1 & (10) & 128.1 & 91.7 & 68.9 \\
\hline 6 & 99.9 & 96.5 & 126.2 & 83.9 & (5) & 119.9 & (9) & 127.6 & 85.1 & 62.6 \\
\hline 7 & 87.8 & 85.7 & 124.3 & 118.0 & (8) & 91.5 & (7) & 126.0 & 119.1 & 49.9 \\
\hline 8 & 94.4 & 81.1 & 124.4 & 109.9 & (8) & 86.2 & (7) & 125.5 & 111.3 & 51.1 \\
\hline 9 & 99.9 & 94.6 & 125.2 & 110.2 & (8) & 132.2 & (12) & 126.4 & 111.6 & 82.2 \\
\hline 10 & 88.3 & 88.4 & 126.0 & 97.8 & $(6)$ & 91.6 & (7) & 127.2 & 98.8 & 44.1 \\
\hline 11 & 97.5 & 95.9 & 127.5 & 255.4 & (20) & 235.5 & (16) & 130.1 & 257.0 & 103.0 \\
\hline 12 & 97.2 & 97.2 & 126.7 & 131.6 & $(7)$ & 138.2 & (11) & 127.6 & 132.5 & 70.2 \\
\hline 13 & 111.9 & 102.7 & 124.7 & 65.6 & (4) & 144.2 & (10) & 125.9 & 66.7 & 71.0 \\
\hline 14 & 83.2 & 83.7 & 124.3 & 187.0 & (12) & 240.8 & (18) & 125.3 & 188.2 & 122.2 \\
\hline 15 & 96.0 & 95.7 & 125.0 & 215.1 & (16) & 247.1 & (17) & 126.4 & 216.4 & 110.3 \\
\hline 16 & 74.3 & 75.2 & 126.2 & 98.9 & (5) & 80.1 & (7) & 127.2 & 100.1 & 43.9 \\
\hline 17 & 82.5 & 85.8 & 124.3 & 96.9 & (5) & 115.7 & (9) & 125.6 & 98.1 & 62.6 \\
\hline 18 & 83.6 & 83.0 & 124.5 & 129.1 & $(8)$ & 137.3 & (10) & 125.6 & 130.3 & 68.8 \\
\hline 19 & 93.0 & 93.0 & 124.9 & 83.5 & (6) & 91.4 & (7) & 125.8 & 84.3 & 52.6 \\
\hline 20 & 79.8 & 79.8 & 124.5 & 109.9 & $(6)$ & 109.4 & (8) & 125.5 & 110.7 & 57.1 \\
\hline ave. & 90.4 & 88.2 & 125.4 & 126.1 & $(8.2)$ & 131.5 & (9.8) & 126.6 & 127.2 & 67.3 \\
\hline
\end{tabular}

Table 3 P.I., CPU time and execution time (Jobshop)

\begin{tabular}{c|rr|rrrrr|rrr}
\hline \hline \multirow{2}{*}{ Run No. } & \multicolumn{3}{|c|}{ P.I. } & \multicolumn{3}{|c|}{ CPU Time [s] (No. of Steps) } & \multicolumn{3}{c}{ Execution Time [s] } \\
\cline { 2 - 11 } & Dist. 1 & Dist. 2 & Cent. & \multicolumn{2}{c|}{ Dist. 1 } & Dist. 2 & Cent. & Dist. 1 & Dist. 2 \\
\hline 0 & 90.6 & 89.1 & 337.0 & 404.8 & $(24)$ & 314.5 & $(23)$ & 338.4 & 407.7 & 178.3 \\
1 & 96.4 & 96.3 & 362.1 & 369.5 & $(25)$ & 394.0 & $(29)$ & 363.6 & 373.1 & 227.0 \\
2 & 106.9 & 102.4 & 387.5 & 492.2 & $(30)$ & 377.5 & $(26)$ & 389.7 & 494.0 & 205.3 \\
3 & 95.8 & 94.9 & 390.8 & 497.1 & $(31)$ & 300.1 & $(22)$ & 392.8 & 498.6 & 215.3 \\
4 & 99.0 & 100.7 & 354.0 & 339.3 & $(20)$ & 238.6 & $(19)$ & 355.6 & 340.8 & 148.6 \\
5 & 97.2 & 104.8 & 384.2 & 324.4 & $(19)$ & 303.1 & $(22)$ & 386.1 & 326.5 & 188.6 \\
6 & 102.0 & 92.0 & 321.9 & 448.7 & $(28)$ & 301.9 & $(22)$ & 323.6 & 451.5 & 176.6 \\
7 & 95.2 & 107.6 & 389.2 & 745.2 & $(45)$ & 307.6 & $(22)$ & 391.1 & 748.5 & 207.6 \\
8 & 105.3 & 103.4 & 401.9 & 276.9 & $(19)$ & 245.3 & $(20)$ & 403.3 & 278.4 & 158.3 \\
9 & 98.7 & 106.3 & 454.6 & 299.3 & $(19)$ & 470.6 & $(32)$ & 457.1 & 301.5 & 255.0 \\
10 & 47.5 & 44.8 & 561.7 & 277.9 & $(19)$ & 290.4 & $(22)$ & 563.7 & 279.8 & 171.7 \\
11 & 87.9 & 88.2 & 386.0 & 405.5 & $(24)$ & 325.8 & $(25)$ & 388.0 & 408.0 & 202.9 \\
12 & 101.0 & 96.8 & 466.6 & 433.3 & $(26)$ & 314.0 & $(24)$ & 468.4 & 435.5 & 182.1 \\
13 & 93.2 & 89.6 & 379.6 & 447.5 & $(31)$ & 360.8 & $(25)$ & 381.7 & 449.7 & 200.9 \\
14 & 90.8 & 94.0 & 371.2 & 297.6 & $(18)$ & 257.5 & $(19)$ & 373.1 & 299.6 & 147.7 \\
15 & 96.7 & 98.1 & 393.6 & 466.4 & $(26)$ & 238.2 & $(19)$ & 396.2 & 468.5 & 155.5 \\
16 & 99.0 & 98.2 & 399.6 & 390.0 & $(23)$ & 383.2 & $(26)$ & 401.6 & 391.9 & 216.0 \\
17 & 99.9 & 103.6 & 335.0 & 357.0 & $(23)$ & 470.2 & $(32)$ & 336.3 & 359.0 & 255.0 \\
18 & 102.1 & 95.8 & 420.8 & 221.1 & $(15)$ & 371.3 & $(27)$ & 424.3 & 222.4 & 218.9 \\
19 & 95.2 & 94.9 & 414.7 & 224.2 & $(14)$ & 301.9 & $(22)$ & 420.4 & 225.9 & 181.9 \\
20 & 87.3 & 86.0 & 356.7 & 362.9 & $(23)$ & 349.9 & $(26)$ & 359.3 & 364.0 & 199.3 \\
\hline ave. & 94.7 & 94.6 & 393.7 & 384.8 & $(23.9)$ & 329.4 & $(24.0)$ & 395.9 & 386.9 & 194.9 \\
\hline \hline
\end{tabular}

開発したシステムの実行性能を評価するため, 切換えコス

卜, 各工程で最後に処理する作業の終了時刻, 納期遅れペナ ルティの重み付き和の最小化を目的とした多工程プロセスの スケジューリング問題を, 開発したシステムと, 全装置のス ケジュールを集中的に作成する従来の手法，および手法自体 は分散型だが 1 台の計算機上で全ての処理を行うシステムに よって解いた。本システムでは各工程が独自に設定された評 価を最適化しているにも関わらず，従来の手法と同程度のス
ケジュールがより短い計算時間で得られることを数值実験に よって確認した．今回は 3 工程のフローショップ問題および ジョブショップ問題を例にとり説明したが, 工程数が増えて も提案したアルゴリスムはそのまま利用できる。

今後の課題として, 情報交換時のデッドロック発生や実行 可能解への収束性に関する厳密な検討を行わなければならな い.また実際の生産現場で使えるシステムとして，進渉管理 システムと連動してローリング・スケジューリングを行う機 
構などの開発を行う必要がある。

$$
\text { 参 考文 献 }
$$

1）宮下和雄：分散環境に抢けるスケジューリング, 生産スケ ジューリング・シンポジウム' 97 講演論文集, pp.203-208, 東 京, Oct.1-2, (1997)

2) Hasebe, S., T. Kitajima, T. Shiren, Y. Murakami and I. Hashimoto, "Autonomous Deccetralized Scheduling System for Single Production Line Processes", AIChE Annual meeting, Paper No.235c, San Francisco, Nov.13-18, (1994)

3) 長谷部伸治, 北島禎二, 橋本伊織：最適化機能を有する自律分 散型スケジューリングシステムの開発, 第 6 回自律分散システ ム・シンポジウム講演要旨集, pp.81-86, 名古屋, Jan.18-19, (1995)

4) Hasebe, S., T. Kitajima and I. Hashimoto, "Application of an Autonomous Deccetralized Scheduling System to Large Scale Problems", AIChE Annual meeting, Paper No.172a, Miami, Nov.12-17, (1995)

5) 北島禎二, 西谷紘一, 齋藤敦彦, 長谷部伸治, 橋本伊織: 並列 装置を有する多工程プロセスの自律分散型スケジューリング システム, 化学工学論文集, 第 22 巻, 第 5 号, pp.1031-1038, (1996)

\section{《付録》}

\section{A. 集中型アルゴリズム}

（1）Table 1 に示したSA 法に関するパラメータ（初期 温度 $T_{0}$, 同一温度での繰り返し数 $N_{T}$, 温度減衰回数 $N_{F}$, 温度減衰比 $h)$ ，初期処理順 $R$ を読み込む.

（2） $R$ に対して，全工程で実行可能な作業開始時刻を前 詰めで決定する。

( 3 ）得られたスケジュールの評価 $f(R)$ を求め, 以下の 変数に值をセットする. $P I \leftarrow f(R), R_{o p t} \leftarrow R, P I_{o p t} \leftarrow$ $P I, T \leftarrow T_{0}, i \leftarrow 0, j \leftarrow 0$.

(4) $i \leftarrow i+1$ とし，与えられた $R$ から作業をランダム に1つ選び，その作業の工程での処理順をランダムに変更 する。そして新たに得られた処理順を $R_{n e w}$ とおく.

（5） $R_{n e w}$ に対して，全工程で実行可能な作業開始時刻 を前詰めで求め，その評価 $f\left(R_{n e w}\right)$ を求める．ただしジョ ブショップ問題では処理順によっては必ずしも実行可能な 開始時刻を求めることができないので，最大完了時刻があ る值以上になったら実行不可能なスケジュールのままつぎ に進む。

(6) $f\left(R_{\text {new }}\right)<P I$ であれば, $R \leftarrow R_{\text {new }}, P I \leftarrow$ $f\left(R_{\text {new }}\right)$ とし, さらに $f\left(R_{\text {new }}\right)<P I_{\text {opt }}$ であれば, $R_{\text {opt }} \leftarrow R_{\text {new }}, P I_{\text {opt }} \leftarrow f\left(R_{\text {new }}\right)$ とする.

（7） $0<p<1$ の一様乱数を発生させ,

$$
p<\exp \frac{\left(P I-f\left(R_{n e w}\right)\right)}{T}
$$

が成立すれば, $R \leftarrow R_{n e w}, P I \leftarrow f\left(R_{n e w}\right)$ とする.

(8) $i<N_{T}$ なら, (4) に戻る.

(9) $i \leftarrow 0, T \leftarrow h \times T, j \leftarrow j+1$ とし、 $j<N_{F}$ であ れば,(4)に戻る。

（10） $R_{o p t}$ を工程のスケジュールとする.

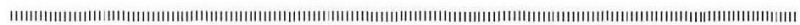

$$
\text { [著者紹 介] }
$$

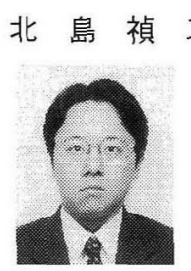

（正会員）

1993 年京都大学工学部化学工学科卒業. 1995 年同大学大学院修士課程修了. 同年奈良先端科学 技術大学院大学情報科学研究科助手, 1998 年豊 橋技術科学大学生産システム工学系助手, プロセ スシステム工学, 生産スケジューリングの研究に 従事 (工学修士).

西 谷 紘 - (正会員)

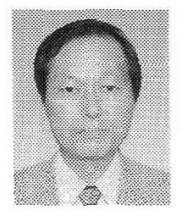

1974 年京都大学大学院工学研究科博士課程化 学工学専攻単位取得退学. 同年大阪大学基礎工学 部助手, 講師, 助教授, 教授を経 $て, 1993$ 年奈良 先端科学技術大学院大学情報科学研究科教授. プ ロセス制御, プロセスシステム工学に関する研究 に従事 (工学博士).

\section{長谷部 伸 治 (正会員)}

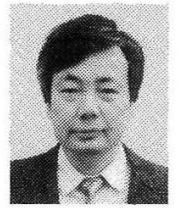

1976 年京都大学工学部化学工学科卒業. 1981 年 同大学大学院博士課程研究指導認定退学. 同年京 都大学工学部化学工学科助手, 講師を経て, 1993 年助教授. プロセスシステム工学, スケジューリ ング, 分離プロセスのシンセシス, バッチ蒸留プ ロ七スの最適設計・操作などの研究に従事 (工学 博士).

\section{橋 本伊織（正会員）}

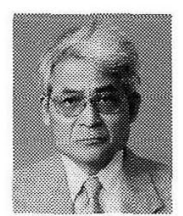

1963 年京都大学工学部衛生工学科卒業. 1968 年同大学大学院博士課程修了. 同年京都大学工学 部衛生工学科助手, 衛生工学科助教授, 化学工学 科助教授を経て, 1989 年教授. プロセスシステム 工学, 化学プロセスの最適設計・操作・制御の研 究に従事 (工学博士)。

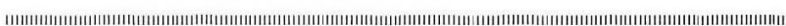

